Selvsagt skal et sykehus drives innen gitte økonomiske rammer, men også den faglige kvaliteten er et topplederansvar. Man beholder ikke jobben som landslagstrener i fotball ved bare å holde budsjettet. Tanken synes å være at sykehus skal styres etter modell av private bedrifter. I næringslivet er imidlertid inntektene avhengige av prestasjonene. Hvis Toyota produserer bedre biler, selger de flere - til høyere pris. Så lenge helsevesenets inntekter i minimal grad er koblet til kvalitet, er det et klart behov for ytre kontrollordninger. Et aktivt helsetilsyn kan her spille en viktig rolle. Det kan også være gunstig med kritisk søkelys fra mediene hvis lyskasterne i større grad rettes mot systemet. Samtidig er det viktig at enkeltmennesker som fronter institusjonens sak får støtte av et profesjonelt apparat. Også for ledere er det vondt å dingle i mediegalgen.

\section{Vi skal varsle om feil}

Ingen virksomhet blir bedre av at feil og svakheter gjemmes bort, og vi bør være glade for at et økende antall pasienter tør klage. For en pasient er dette nemlig lettere sagt enn gjort når hun er avhengig av dem hun vil klage på. Trolig bør vi leger selv ta et større ansvar for å melde fra om feil, særlig fordi vi har gode forutsetninger for å oppdage de alvorlige avvikene. Det er grunn til å tro at uheldige forhold aldri blir avdekket fordi den mulige varsler frykter uforholdsmessig store konsekvenser for en kollega.

Hvis helsearbeidere skal bli varslere, må vi kunne ha tillit til at institusjonen tar på seg ansvaret og at tilsynsmyndighetene handler raskt og uten å la seg drive dit vinden blåser. Derfor handler ikke kampen mot urettmessig medieforfølgelse bare om å beskytte den forfulgte - det handler også om å legge til rette for at reelle feil avdekkes og stimulere et økonomisk presset helsevesen til å ivareta kvaliteten på systemnivå.

\section{Jon Amund Kyte}

jon.amund.kyte@rr-research.no

Oslo universitetssykehus
Jon Amund Kyte (f. 1972) er konstituert overlege ved Oslo universitetssykehus, Radiumhospitalet, og medisinsk redaktør i Tidsskriftet. Han har doktorgraden innen immungenterapi mot kreft. Ingen oppgitte interessekonflikter.

Litteratur

1. Ekeberg $\emptyset$. Ambulansesaken - noe å lære av? Tidsskr Nor Legeforen 2010; 130: 1732-4.

2. Østtveit K. Syndebukkene. A-magasinet 24.6.2011: 9-17.

3. Avslutning av tilsynssak. Statens helsetilsyn 11.5.2011. www.helsetilsynet.no/no/Tilsyn/ Tilsynssaker/Ingen-reaksjon-lege-gastrokirurgi/ (15.8.2011).

4. Avslutning av tilsynssak. Statens helsetilsyn 11.5.2011. www.helsetilsynet.no/no/Tilsyn/ Tilsynssaker/Ingen-reaksjon-lege-kirurgi-kreft/ (15.8.2011).

5. Stoltenberg K, Østtveit K. Sannhetsvitnene. A-magasinet 7.1.2011: 9-15.

6. Arbeidstilsynets rapport 1.7.2011 www.oslo-universitetssykehus.no/ SiteCollectionDocuments/Aktuelt/Rapporter (13.10.2011).

\title{
Tidsskriftet på dørmatten - en sikkerhetsrisiko?
}

\author{
Tidsskriftet har et ansvar for legers personvern.
}

Jeg er av dem som nå får Tidsskriftet levert uadressert sammen med avisene - i mitt tilfelle til min egen postkasse i et fellesstativ for ti hus. Hver postkasse er merket med navn, men det er ingen andre personopplysninger på dem. Jeg er for tiden eneste lege i postkassestativet og forstår at det er rasjonelt for budet å merke min kasse, fordi han ellers hver gang måtte ha konsultert sin egen adresseliste over mottakere av Tidsskriftet.

De første leveringene fungerte greit, men siste gang registrerte jeg at min postkasse var påført en gul plastremse påtrykt «LEGE». Fordi jeg har bodd i området i flere tiår, kjenner naboene til mitt yrke. Men folk med kriminelle hensikter som eventuelt bruker postkassene til å skille ut potensielle ofre, får med denne merkingen informasjon som øker risikoen for innbrudd, fordi man ofte feilaktig forestiller seg at leger oppbevarer for eksempel morfinpreparater til bruk i praksisen også i sitt hjem.

Denne forestillingen var trolig årsaken til en rekke innbrudd i legehjem i Molde for vel 20 år siden. Grunnet frykt for at dette kunne spre seg til Ålesund installerte jeg Falkenalarm og har vært forskånet for innbrudd.
Publikum er de siste årene gjennom massemediene gjentatte ganger blitt advart om faren for misbruk av personalopplysninger som mer «profesjonelle» kriminelle kan få fatt i via blant annet postkassene. Selv om forestillingen om at leger er velstående er dempet med årene, kan man likevel anta at dette - sammen med illusjonen om oppbevaring av vanedannende medikamenter gjør det uakseptabelt å identifisere en leges privatadresse på denne måten.

Jeg antar at hovedformålet med nyordningen er å redusere omkostningene ved utsending av Tidsskriftet og at de forskjellige distributører kan ha forskjellige praktiske løsninger, som ikke alle er så ille som den jeg opplever. Jeg vil likevel hevde at Tidsskriftet må ha et overordnet ansvar for at vi som yrkesgruppe ikke blir utsatt for ubehagelige konsekvenser grunnet brudd på personvernet.

\section{Odd Johan Frisvold}

ojofrisv@online.no

Ålesund
Odd Johan Frisvold (f. 1934) er spesialist i indremedisin og i hjertesykdommer. Han er pensjonert avdelingsoverlege ved medisinsk avdeling og tidligere sjeflege ved Sentralsjukehuset i Møre og Romsdal.

Ingen oppgitte interessekonflikter.

Mottatt 14.11. 2011 og godkjent 17.11. 2011 Medisinsk redaktør Anne Kveim Lie.

\section{Redaksjonen kommenterer:}

Fra i høst har vi prøvd ut en ny distribusjonsmåte der omtrent halvparten av abonnentene får Tidsskriftet levert via bud og ikke med Posten. Bakgrunnen for prøveprosjektet er at portokostnadene er blitt uforholdsmessig høye. Tilbakemeldinger som dette er viktige for oss når ordningen snart skal evalueres. Vi mottar gjerne spørsmål eller kommentarer om leveringen på e-post tiltidsskriftet@legeforeningen.no eller telefon 23109050 .

\section{Charlotte Haug}

Tidsskriftet 